\title{
PELAKSANAAN PROGRAM SEKOLAH BERWAWASAN GENDER DI PROPINSI RIAU
}

\author{
Yenita Roza 1), dan Rahmita B.N. Lutfi.,2) \\ 1). FKIP Universitas Riau, email: yenita.roza@lecturer.unri.ac.id \\ 2) Fakultas Ekonomi Universitas Riau
}

\begin{abstract}
Gender mainstreaming being the big issues lately included in Indonesia. To improve the gender equality access for education Indonesian government been launching the schools program name "Sekolah Berwawasan Gender". The aim of this study is to explore the schools' achievement on that government program in The Province of Riau. Giving orientation program, schools were required to design and implement their specific program. Schools also get funded to accelerate their program. The assessment were done based on 10 standard on indicator of the program implementation. Data were collected through questionnaire and direct observation to the schools. This paper discuss finding based on the 10 standard that grouped into schools level and region of the schools. It was found that the highest achievement is reached for standard $3(85 \%)$ that deal with learning outcome, the lowest achievement is given to the standard 5 (56\%) about schools' facilities. This finding will be used as recommendation for the schools and government to improve their program design and implementation of gender equality program.
\end{abstract}

Key Word :sekolah, wawasan gender, pendidikan

\section{PENDAHULUAN}

Dalam dekade terakhir ini, upaya penyadaran gender menjadi perbincangan serius di kalangan aktivis perempuan, keluarga-keluarga, wartawan, dunia pendidikan maupun kalangan politisi. Berbagai-strategi penyadaran telah ditawarkan dengan tujuan agar kesetaraan gender dalam berbagai bidang kehidupan masyarakat terwujud. Sepertinya strategi yang ditawarkan belumlah mampu mewujudkan kestraan yang diinginkan karena kesenjangan tetap saja terjadi dalam berbagai bidang kehidupan masyarakat.

Berbagai bentuk kesenjangan gender yang terjadi dalam berbagai bidang kehidupan masyarakat, terpresentasi juga dalam dunia pendidikan. Bahkan proses dan institusi pendidikan dipandang berperan besar dalam mensosialisasikan dan melestrikan nilai-nilai dan cara pandang yang mendasari munculnya berbagai ketimpangan tersebut.

Secara garis besar, fenomena kesenjangan gender dalam pendidikan dapat diklasifikasi dalam beberapa dimensi, antara lain: (1) kurangnya partisipasi (under-participation). Dalam hal partisipasi pendidikan, perempuan di seluruh dunia menghadapi problem yang sama. Dibanding lawan jenisnya, partisipasi perempuan dalam pendidikan formal jauh lebih rendah Dinegara-negara dunia ketiga di mana pendidikan dasar belum diwajibkan, jumlah murid perempuan umumnya hanya separuh atau sepertiga jumlah murid laki-laki,1⑵ Kurangnya keterwakilan (under-representation). Partisipasi perempuan dalam pendidikan sebagai tenaga 
pengajar maupun pimpinan juga menunjukkan kecenderung disparitas progresif. Jumlah guru perempuan pada jenjang pendidikan dasar umumnya sama atau melebihi jumlah guru laki-laki. Namun, pada jenjang pendidikan lanjutan dan pendidikan tinggi, jumlah tersebut menunjukkan penurunan drastis. (3) Perlakuan yang tidak adil (unfair treatment) Kegiatan pembelajaran dan proses interaksi dalam kelas seringkali bersifat merugikan murid perempuan. Guru secara tidak sadar cenderung menaruh harapan dan perhatian yang lebih besar kepada murid laki-laki dibanding murid perempuan. Para guru kadangkala cenderung berpikir ke arah "self fulfilling prophecy" terhadap siswa perempuan karena menganggap perempuan tidak perlu memperoleh pendidikan yang tinggi.

Menurut Philip Robinson, ketimpangan dalam pendidikan dapat dibedakan menjadi dua, yaitu ketimpangan pada akses terhadap pendidikan dan ketimpangan pada hasil atau outcome pendidikan. ${ }^{2}$ Laporan departemen pendidikan yang penyusunannya dibiayai UNICEF, juga menjelaskan bahwa kondisi pendidikan di Indonesia sangat memprihatinkan, khususnya bagi anak perempuan yang ingin melanjutkan pendidikan kesekolah menengah, atau mereka yang berasal dari keluarga miskin dan tinggal di pedesaan.

Selain itu juga ditemukan gejala pemisahan gender dalam jurusan atau program studi sebagai salah satu bentuk diskriminasi gender secara sukarela ke dalam bidang keahlian. Pemilihan jurusan-jurusan bagi anak perempuan lebih dikaitkan dengan fungsi domestik, sementara itu anak laki-laki diharapkan berperan dalam menopang keonomi keluarga sehingga harus lebih banyak memilih keahlian-keahlian ilmu keras, teknologi dan industri. Penjurusan pada pendidikan menengah kejuruan dan pendidikan tinggi menunjukkan masih terdapatnya stereotype dalam sistem pendidikan di Indonesia yang mengakibatkan tidak berkembangnya pola persaingan sehat menurut gender. Sebagai contoh, bidang ilmu sosial pada umumnya didominasi siswa perempuan, sementara bidang ilmu teknis umumnya didominasi siswa laki-laki. Pada tahun ajaran 2000/2001,persentase siswa perempuan yang bersekolah di SMK program studi teknologi industri baru mencapai 18,5 persen, program studi pertanian dan kehutanan 29,7 persen.

Sedangkan ketimpangan pada hasil pendidikan adalah perbedaan akhir pendidikan.Ketimpangan pada hasil pendidikan menunjukkan adanya perbedaan antara laki-laki dan perempuan pada prestasi pendidikan.Prestasi di antara mereka tidak sepadan.Prestasi laki-laki lebih tinggi atau lebih baik daripadaperempuan.Ketimpangan akses pendidikan dapat berdampak pada feminisasi dalam pendidikan. Ketidaksamaan kesempatan dalam pendidikan antara lakilaki dan perempuan akan berdampak pada kecenderungan melihat bahwa perempuan hanya bisa diterima pada sistem pendidikan tertentu. Di masyarakat berkembang sikap bahwa perempuan hanya cocok pada jenis 
pendidikan tertentu dan tidak pantas memilih sistem pendidikan lainnya.

Dengan rendahnya tingkat pendidikan penduduk yang berjenis kelamin perempuan maka, secara otomatis perempuan belum berperan secara maksimal. Pencanangan wajib belajar pada usia 6 tahun pada tahun 1984 dan program wajib belajar 9 tahun pada tahun 1994, belum memberikan hasil yang signifikan terhadap perempuan. Terjadinya pengingkaran dan diskriminasi terhadap hak-hak perempuan seperti yang digambarkan di atas, menurut Masdar F. Mus'udi pangkal mulanya adalah disebabkan oleh adanya pelebelan sifat-sifat tertentu pada kaum perempuan yang cenderung merendahkan. Misalnya perempuan itu lemah, lebih emosional ketimbang nalar, cengeng, tidak tahan banting, tidak patut hidup selain di dalam rumah tangga. Setidaknya ada empat persoalan yang menimpa perempuan akibat adanya pelebelan ini ${ }^{1}$. Pertama, melalui proses subordinasi (meletakkan perempuan di bawah supremasi lelaki), perempuan harus tunduk kepada sesame manusia, yakni kaumlelak. Pemimpin atau imam hanya pantas dipantas dipegang oleh laki-laki, perempuan hanya bolehh menjadi makmum saja. Kedua, perempuan cenderung dimarginalkan, diletakkan di pinggir. Ketiga, karena kedudukannya yang lemah, perempuan sering menjadi sasaran tindak kekerasan oleh kaum laki-laki. Keempat, perempuan hanya menerima beban pekerjaan yang jauh lebih berat dan lebih lama daripada yang dipukul kaum laki-laki.

Faktor lain yang turut mempengaruhi bias gender dalam pendidikan adalah muncul persaingan dengan teknologi yang menggantikan peranan pekerja perempuan dengan mesin. Dampaknya, lagi-lagi perempuan menjadi korban teknologi khususnya perempuan yang memiliki tingkat pendidikan rendah ditambah pula dengan kemampuan ekonomi yang masih lemah. ${ }^{3}$

Propinsi Riau merupakan sebuah propinsi yang berkomitmen mewujudkan kesetraan gender. Salah satu bentuk komitmen tersebut ditunjukkan melalui penetapkan sekolah berwawasan gender dengan melakukan beberapa tahap seperti sosialisasi ke semua kabupaten/kota di provinsi Riau, selanjutnya melakukan peninjauan kepada sekolah yang sudah mulai berwawasan gender. Saat ini tahap yang dilakukan oleh pemerintah Provinsi melalui Dinas Pendidikan Provinsi Riau adalah memberikan bantuan kepada sekolah yang dianggap sudah merespon kegiatan sekolah berwawasan gender tersebut.

Sekolah berwawasan gender adalah : suatu sekolah yang baik aspek akademik, sosial, aspek lingkungan fisiknya, maupun lingkungan masyarakatnya memperhatikan secara seimbang baik kebutuhan spesifik untuk laki-laki maupun perempuan. Dengan 
demikian gutu, orang tua, tokoh, anggota masyarakat di sekitarnya, serta siswa lakilaki dan perempuan menyadari akan pentingnya, dan oleh karena itu mempraktekkan tindakan-tindakan yang setara dan adil gender.

$$
\text { Sedangkan ciri-ciri sekolah }
$$

berwawasan gender, antara lain : (1).

Kepemimpinan dilakukan secara horisontal dan team work kooperatif yang ramah terhadap perbedaan. Selain itu, manjemen tidak menawarkan peran stereotipi gender sehingga menghalangi capaian target sekolah; (2). Pembagian peran atau posisi fleksibel tergantung pada kebutuhan, kesempatan, komitmen dan kualitas serta pembakuan peran / posisi secara ketat banyak menimbulkan masalah ( stereotipi, subordinasi, marginalisasi, beban lebih, kekerasan; mekanisme pengambil keptusan seimbang dan memperhatikan qouta minim $30 \%$ dari perempuan; menghargai perbedaan gaya, cara kerja laki-laki dan perempuan harus dimaknai sebagai kekuatan selama mencapai target; budaya sekolah harus menghindari perilaku yang stereotipi, diskriminatif, merendahkan salah satu jenis kelamin dan ; manajemen yang ramah terhadap perempuan, bahan pajangan kantor, kalender, poster, screen komputer tidak boleh melecehkan salah satu jenis kelamin; mendorong dan membantu setiap individu untuk maju dan setara.Penulisan makalah ini bertujuan mengekplore kesiapan sekolah di berbagai jendang dalam merencanakan dan menjalankan pendidikan berwawasan gender.Disamping itu temuan ini menjadi dasar untuk memberikan saran kepada sekolah maupun Dinas Pendidikan Propinsi Riau untuk meningkatkan kemampuan sekolah memberikan pelayanan yang berwawaan gender.

\section{METODE PENELITIAN}

Penilaian sekolah berwawasan gender telah dilakukan sejak tahun 2014 di Propinsi Riau. Kegiatan dilakukan dalam beberapa tahapan yang dimulai dengan permintaan dari dinas pendidikan tingkat Propinsi ke semua kabupaten untuk mengirim utusan ke propinsi untuk mengikuti sosialisasi dan pelatihan. Setiap Kabupaten diminta mengirim satu utusan dari TK, SD, SMP, SMA dan SMK. Peserta utusan kabupaten ini mengikuti sosialisasi dan pelatihan dengan materi penjelasan program Sekolah Berwawasan Gender dan persiapan yang perlu mereka lakukan untuk implementasi program.

Peserta pelatihan diminta untuk menyiapkan sekolah mereka untuk dinilai oleh tim reviewer akan kesiapan mereka menjalankan program. Terdapat 12 TK, 11 SD, 12 SMP, 9 SMA dan 10 SMK yang berpartisipasi pada kegiatan ini. Dari hasil penilaian terhadap 54 sekolah yang dinilai maka 15 sekolah diundang ke tingkat propinsi untuk menyajikan program mereka. Sekolah-sekolah ini diberikan dana untuk akselerasi pelaksanaan sekolah berwawasan gender. 
Pada tulisan ini data kesiapan sekolah yang dikumpulkan dibagi dalam 10 bagian sesuai dengan standar pada indikator sekolah berwawasan gender.Data diolah dan dianalisa menurut jenjang pendidikan dan kabupaten asal sekolah.

\section{PEMBAHASAN}

Hasil pengolahan data dari penilaian sekolah dikelompokkan dan dianalisa berdasarkan sepuluh standar indikator sekolah berwawasan gender. Data ini dibandingkan berdasarkan jenjang pendidikan dan kabupaten tempat sekolah berada.

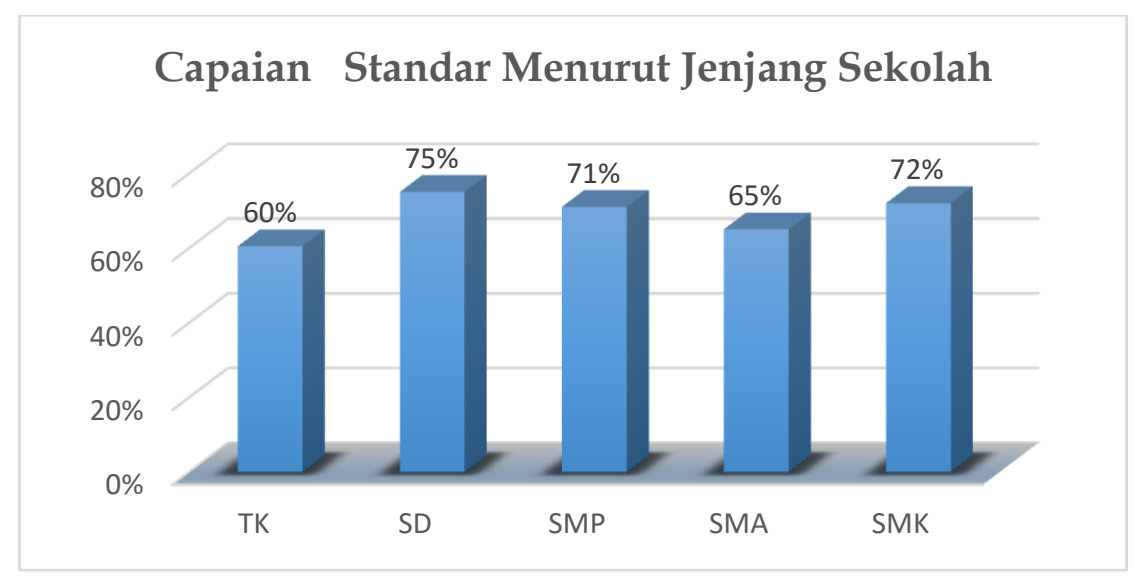

Grafik 1: Perbanding Capaian Menurut Jenjang Sekolah

Grafik diatas mengambarkan capaian rata-rata dari sepuluh standar yang dikelompokkan menurut jenjang sekolah. Capaian terbaik ada ditingkat SD dan terendah di tingkat TK. Secara umum capaian ini belum memuaskan, namun demikian untuk penilaian tahap awal sekolah-sekolah ini mempunyai potensi dan keinginan yang sangat tinggi untuk menjalankan program sekolah berwawasan gender. Jarak waktu sosialisasi dan penilaian yang terlalu dekat membuat sekolah tidak dapat memaksimalkan kegiatan mereka.

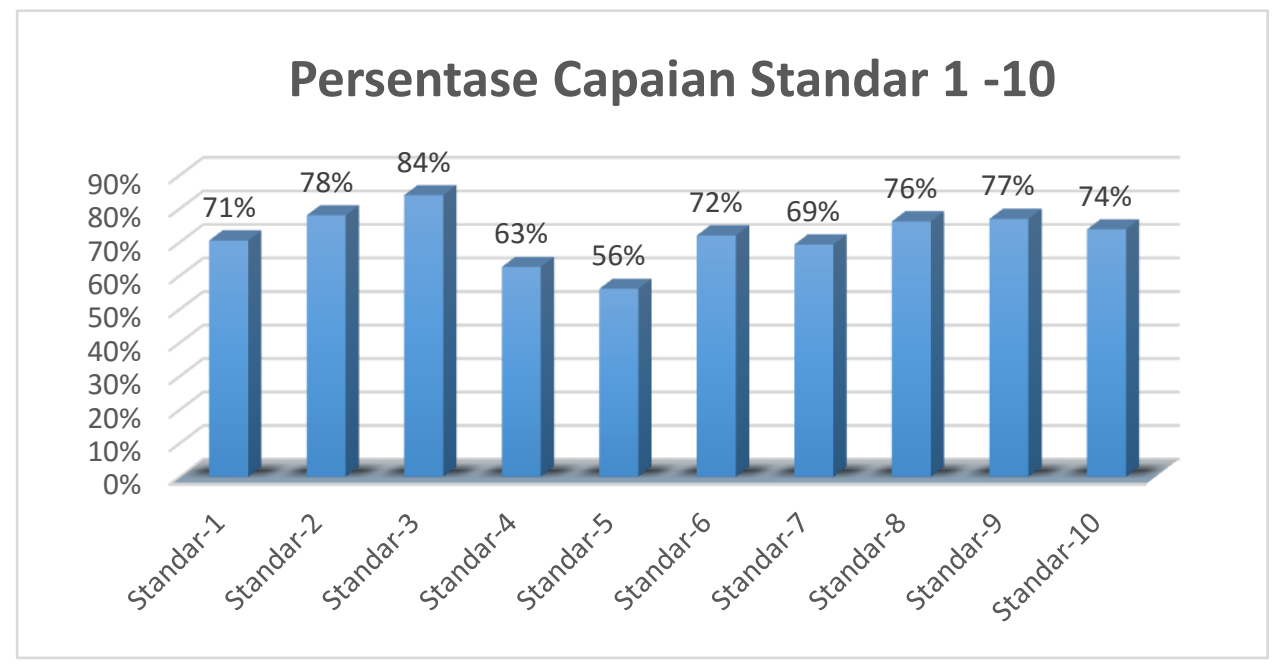




\section{Grafik 2: Persentase Capaian Standar 1-10}

Pada grafik diatas diperlihatkan rataan capaian setiap standar pada semua sekolah mulai dari TK sampai SMA/SMK. Standar yang paling rendah capaiannya adalah standar 5 tentang sarana dan prasarana.Penilaian pada standar ini lebih bersifat kuantitatif karena langsung melihat secara phisik jumlah dan keberimbangan sarana dan prasarana untuk siswa laki-laki dan perempuan. Standar lain yang masih rendah capaiannya adalah standar 4 mengenai standar Tenaga Pendidik dan Tenaga Kependidikan. Pada standar ini dituntut keberimbangan jumlah guru lakilaki dan perempuan, sedangkan secara umum jumlah guru perempuan lebih banyak dari guru laki-laki. Namun demikian masih ditemukan permasalahan dalam ketimpangan kesempatan untuk pengembangan diri. Capaian tertinggi dan satu-satunya capaian diatas $80 \%$ adalah pada standar kelulusan. Standar ini menuntut zero HIV dan narkoba, dimana hampir semua sekolah sudah memiliki kriteria ini.

Dari temuan lapangannsekolah sebetulnya menyatakan sudah tidak mempermasalahkan gender ditempat mereka namun demikian semuanya berjalan tanpa diprogramkan sesuai tuntutan program sekolah berwawasan gender. Pada standar proses sekolah menyatakan tidak membedakan tindakan terhadap siswa lakilaki dan perempuan dalam proses pembelajaran namun juga tidak dapat memperlihatkan RPP yang menyatakan rencana bahwa mereka akanmemperlakukan siswa secara setara.

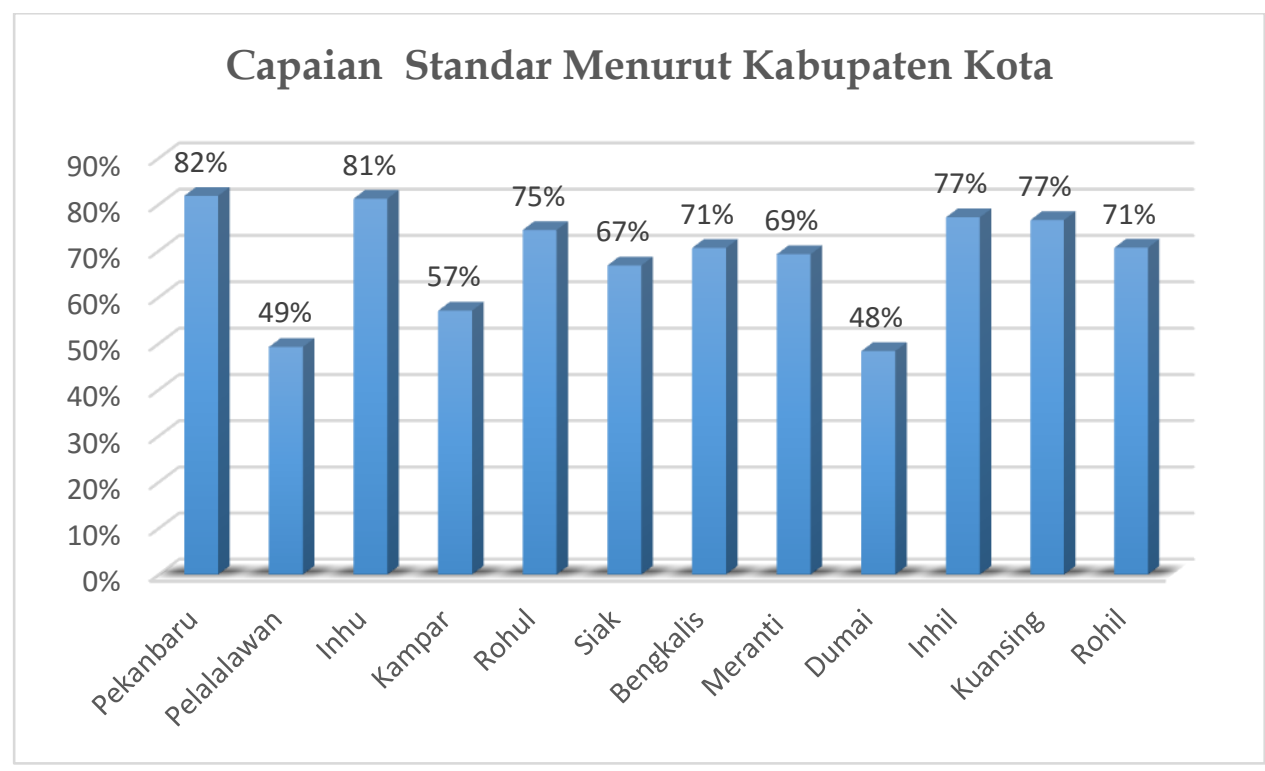

Grafik 3: Capaian Sekolah Menurut Kabupaten/Kota 
Pada kegiatan penilaian sekolah berwawasan gender setiap kabupaten diminta untuk mengirim 5 sekolah utusan, namun tidak semua kabupaten/kota memenuhi permintaan. Hanya untuk level SMP yang semua kabupaten mengirimkan utusanya. Kota Dumai paling sedikit mengirim utusannya, hanya dua sekolah yaitu untuk level TK dan SMP. Dari hasil penilaian kabupaten ini juga mendapatkan nilai terendah. Kabupaten yang lengkap mengirim utusan adalah Kabupaten Pelalawan, Inhu, Rohul dan Bengkalis. Namun demikian kelengkapan utusan tidak mengambarkan kualitas pelaksanaan program. Kabupaten Pelalawan sudah mengirim 5 utusan namun nilai yang didapat masih rendah.Kondisi terbaik didapatkan oleh kabupaten Inhu dan Kota Pekanbaru.
Berikut ini dibahas capaian masingmasing standar menurut jenjang sekolah:

\section{Capaian berdasarkan standar nasional pendidikan}

(1) Capaian Indikator Standar Isi. Standar pada standar ini terdapat 5 indikator yaitu pemilihan materi muatan lokal yang responsive gender yaitu rancangan pembelajaran untuk mewujudkan lingkungan belajar yang kondusif untuk mendorong keadilan dan kesetaraan gender, rancangan dan pelaksanaan materi ajar yang berkeadilan gender, peluang yang sama bagi siswa laki dan perempuan dalam menggunakan media pembelajaran serta fungsi media dalam mendorong siswa laki dan perempuan untuk dapat kosentrasi dalam belajar.

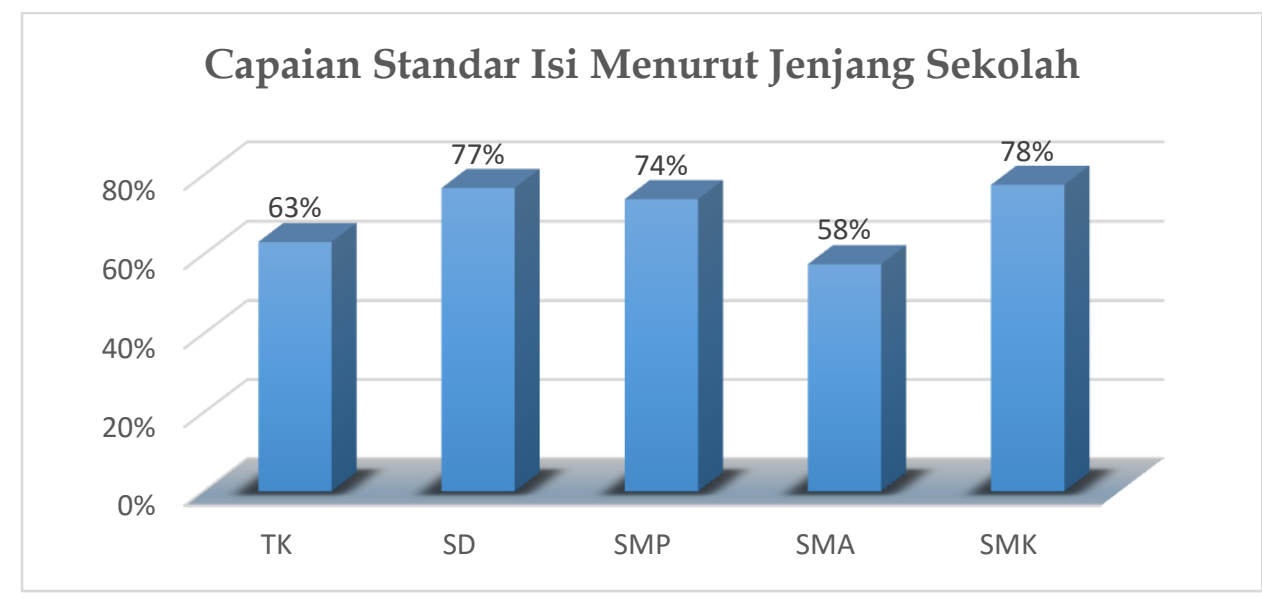

Grafik 4: Capaian sekolah pada Standar Isi

Dari Grafik diatas dapat dilihat rendah dibandingkan jenjang sekolah capaian pada level TK/Paud dan SMA lebih lainnya.Hal ini terjadi karena pada level 
TKmereka belum memprogram perbedaan kegiatan dan fasilitas mengingat usia murid yang mengikuti pendidikan. Pada tingkat SMA kebutuhan akan perbedaan justru sangat terasa tetapi sekolah belum bisa memfasilitasi.

(2) capaian Indikator Standar Proses Standar ke dua merupakan standar proses, standar ini memastikan bahwa siswa laki-laki dan perempuan mendapatkan akses yang sama dalam proses pembelajaran. Terdapat Sembilan pertanyaan pada standar proses ini yang mengatur kesempatan siswa dalam mengemukan gagasan, keaktifan dan kerjasama dalam diskusi kelompok. Karena pengalaman social yang beragam maka melalui standar ini guru juga diminta untuk memfasilitasi cara belajar yang beragam serta memberikan kesempatan dan perhatian yang sama untuk aktif belajar dan mengambil kesimpulan dari sebuah pembelajaran. Terlepas dari proses pembelajaran, sekolah juga dituntut untuk memberikan kesempatan yang sama bagi siswa untuk menjadi pemimpin kelas mereka. Guru juga dituntut untuk memberikan contoh tokoh yang sukses secara berimbang antara tokoh laki dan perempuan.

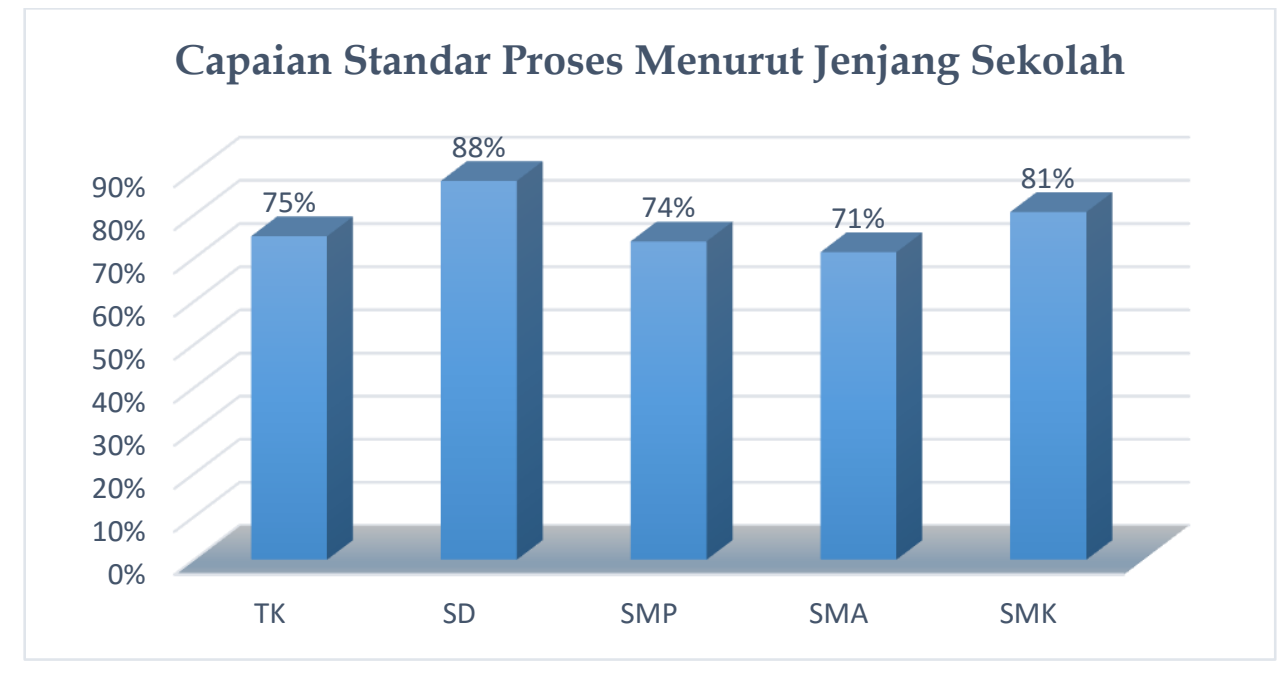

Grafik 5: Capaian sekolah pada Standar Proses

Pada Grafik 5 diatas dapat dilihat capaian standar proses pada semua sekolah dapat dikatakan baik. Secara umum pada semua level mereka tidak membedakan siswa laki-laki dan perempuan dalam proses belajar. Semua murid dapat kesempatan yang sama dalam mengemukakan pendapat ataupun mengerjakan tugas dikelas. Guru yang diwawancara mengatakan ini sudah berjalan sejak lama bukan karena diprogramkan untuk sekolah berwawasan gender.Pada standar proses yang masih terlihat masalah kesetaraan gender adalah pada materi atau contoh-contoh yang digunakan guru dalam pembahasan materi.Kesulitan yang dihadapi pada standar 
proses ini adalah memilih pada materi apa konteks gender bisa diintegrasikan dan cara menyusun rencana pembelajaran yang berwawasan gender.

(3) Capaian Indikator Standar Kelulusan. Standar Kelulusan mengatur empat hal yaitu kewajiban bagi siswa lakilaki dan perempuan untuk saling mehargai, terciptanya kondisi adil dan aman dalam kehidupan bersama serta tidak terjadi pelecehan sek dan kekerasan baik terhadap siswa laki-laki maupun perempuan. Satu hal lagi yang sangat penting dari standar kelulusan adalah zero point pengidap HIV bagi siswa.

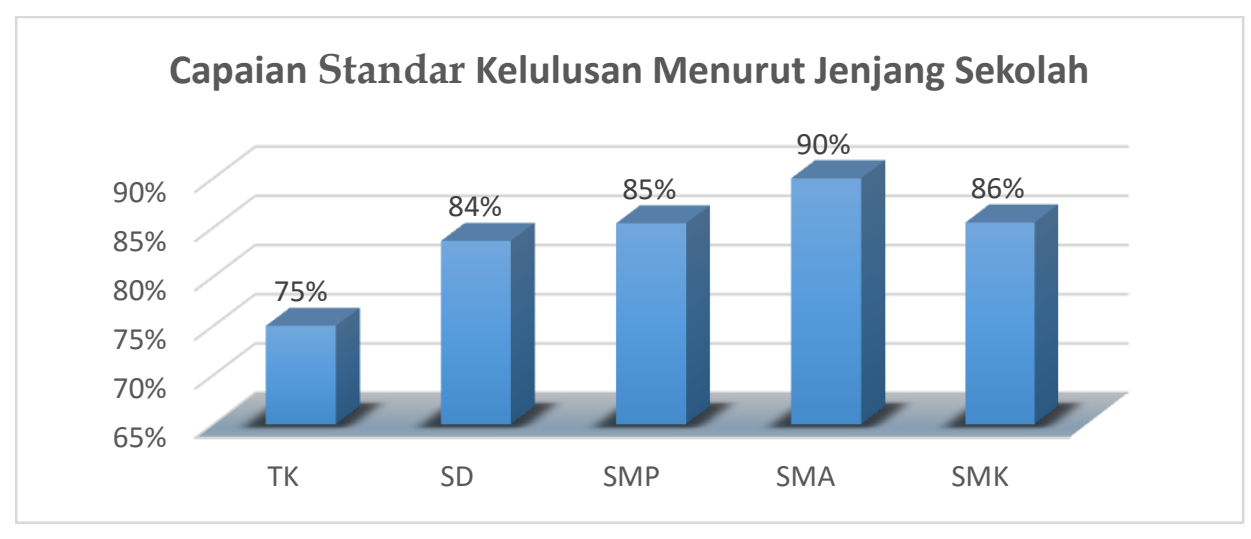

Grafik 6: Capaian Sekolah pada Standar Kelulusan

Grafik 6 diatas memperlihatkan capaian sekolah pada semua tingkatan dengan hasil yang baik untuk standar kelulusan. Secara umum untuk semua standar, capaian standar kelulusan paling tinggi dibandingkan standar lainnya.Tidak ada sekolah yang bermasalah dengan HIV, sekolah yang bermasalah dengan narkoba sangat sedikit. Masalah penghargaan terhadap semua gender berjalan baik, meskipun ada masalah pelecehan seksual masih pada batas yang dapat segera diatasi oleh sekolah sehingga tidak berkelanjutan.

(4) Capaian Indikator Standar Tenaga Pendidik dan Kependidikan. Standar keempat mengatur hal-hal yang berkaitan dengan Pendidik dan Tenaga Kependidikan. Melalui standar ini dituntut adanya keberimbangan antara jumlah guru laki-laki dan perempuan. Keberimbangan ini tidak hanya dari jumlah tetapi juga dari proporsional dari jenjang pendidikan dan keterlibatan dalam inservise training. Promosi jabatan juga dituntut untuk dilakukan secara berimbang, hal ini juga berlaku untuk tenaga kependidikan seperti pustakawan, laboran dan lain-lain. Standar ini juga mengatur agar berkurangnya kekerasan fisik terhadap siswa, tidak ada guru yang meminta pungutan terhadap siswa serta pemberian bimbingan studi lanjut yang sama untuk semua siswa 


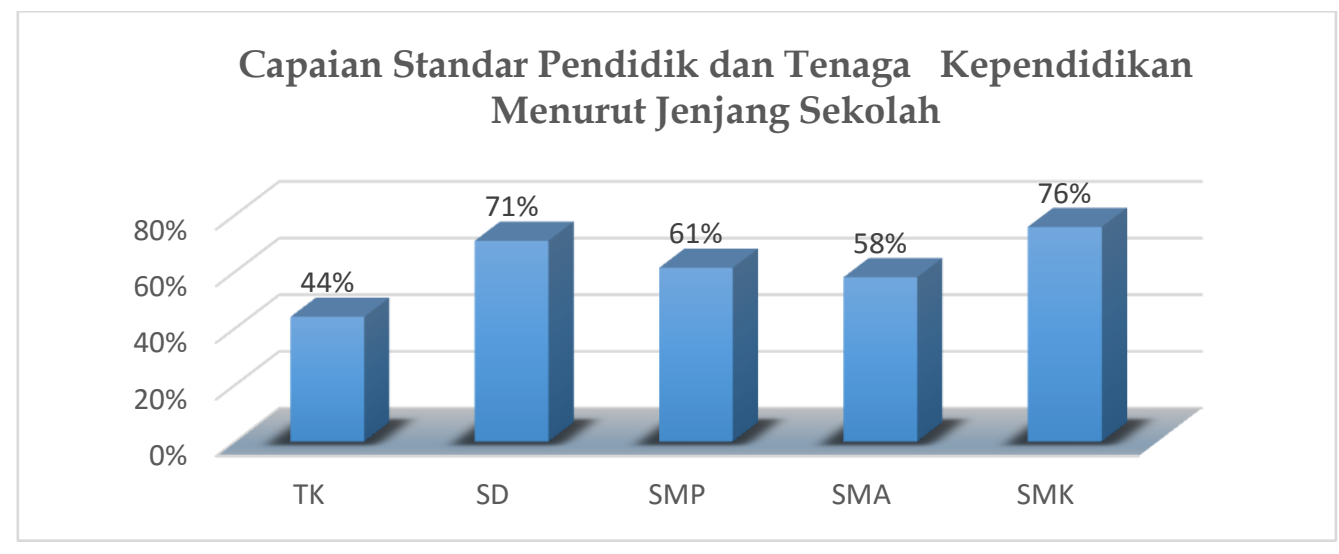

Grafik 7: Capaian Sekolah pada Standar Pendidikan dan Tenaga Kependidikan

Capaian pada Standar Pendidik dan tenaga kependidikan sangat bervariasi antar jenjang pendidikan. Hasil terendah didapatkan pada tingkat TK dan paling baik pada SMA. Sebetulnya rendahnya tingkat capaian ditingkat TK tidaklah menunjukan hal yang mengkawatirkan karena salah satu poin yang dinilai adalah keberimbangan jumlah guru laki-laki dan perempuan, sedangkan secara umum guru TK adalah perempuan. Permasalahan lain yang ditemukan pada standar ini adalah kesempatan yang sama untuk mendapatkan pengembangan diri, meskipun masalah utama bukan soal gender tetapi penunjukan yang tidak merata da nada kecendrumgan menugaskan orang yang sama untuk ikut pelatihan berkali-kali.
(5) Capaian Indikator Standar Sarana dan PrasaranaStandar Sarana dan Prasana merupkan standar yang sangat mudah untuk dilihat secara phisik sehingga sering mendapatkan perhatian lebih baik dari pihak sekoah maupun pihak penilai. Pada standar ini diatur keberadaan toilet, tempat duduk dikelas, media yang digunakan. Untuk kenyamanan dan keamanan siswa pada standar ini juga diatur ketersediaan taman, alat bermain, pagar sekolah serta adanya CCTV untuk memantau keamanan. Untuk layanan kesehatan dan ibadah juga diatur ketersedian ruang BK dan UKS, ruang ganti dan tempat ibadah.Ruang ini diharapkan tersedia secara terpisah untuk siswa laki-laki dan perempuan. 


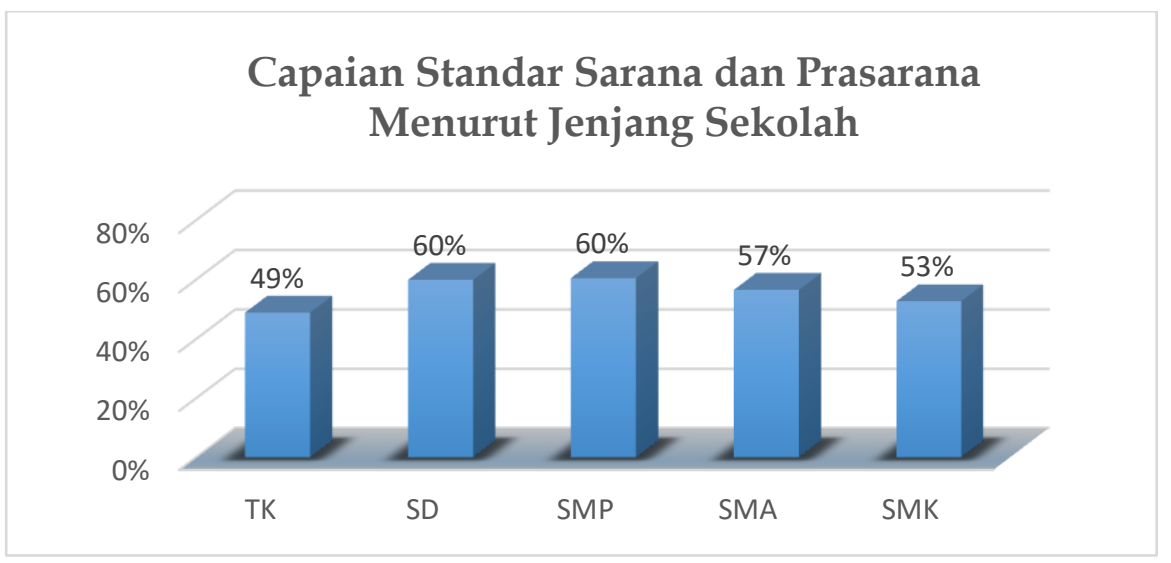

Grafik 8: Capaian Sekolah pada Standar Sarana dan Prasarana

Capaian pada standar sarana dan prasarana pada semua jenjang sekolah seperti ditampilkan pada grafik diatas hanya mencapai 60 persen. Pada standar ini semua fasilitas dapat dilihat secara langsung sehingga penilaian lebih objektif. Semua sekolah sudah memilah antara toilet siswa laki-laki dan perempuan namun masih banyak sekolah yang memposisikan toilet laki-laki dan perempuan secara berdampingan. Permasasalah yang ditemukan hampir disemua sekolah adalah jumlah toilet yang belum berimbang dengan jumlah murid dan jumlah toilet laki-laki dan perempuan tidak dibedakan. Hanya beberapa sekolah yang menyediakan fasilitas yang berbeda untuk toilet laki-laki dan perempuan seperti tempat sampah dan gantungan tas. Permasalahan umum yang juga ditemukan disekolah adalah tidak tersedianya atau minimnya ketersediaan tempat ganti pakaian bagi siswa perempuan setelah olah raga, sehingga mereka harus ganti pakaian di toilet atau tempat lain yang kurang tertutup.
Sekitar 50\% sekolah sudah memberikan fasilitas yang berbeda untuk UKS ataupun ruang BK, meskipun mereka masih menggunakan ruang yang sama tetapi sudah ada sekat yang membedakan ruang laki-laki dan perempuan. Untuk fasilitas media belajar, ketersediaan pagar sekolah ataupun tempat bermain tidak ditemukan masalah yang berarti.Tempat duduk dikelas secara umum sekolah memisahkan untuk siswa laki-laki dan perempuan dan juga memberikan perhatian pada perbedaan phisik seperti tinggi siswa dan juga untuk siswa yang bermasalah dengan jarak pandang.

(6) Capaian Indikator Standar Pengelolaa. Standar Pengelolaan digunakan untuk mengatur terjaminnya terlaksana kesetaraan gender di sekolah. Pengaturan dimulai dengan visi dan misi sekolah yang memuat jaminan tersebut. Nilai dan norma sekolah harus bisa diterima oleh laki-laki dan perempuan. Aktifitas dan peraturan dan bantuan edukatif pembelajaran yang dibuat sekolah harus dapat diakses, dimanfaatkan 
dan dikontrol oleh siswa laki-laki dan perempuan.Pada standar pengelolaan juga diatur temuan, teguran dan arahan yang diberikan oleh pengawas. Struktur organisasi sekolah dan penugasan kepada guru harus dilakukan secara berimbang untuk guru dan staf laki-laki dan perempuan. Keputusan yang dilakukan pada rapat harus dimusyawarahkan secara bersama antara laki-laki dan perempuan.

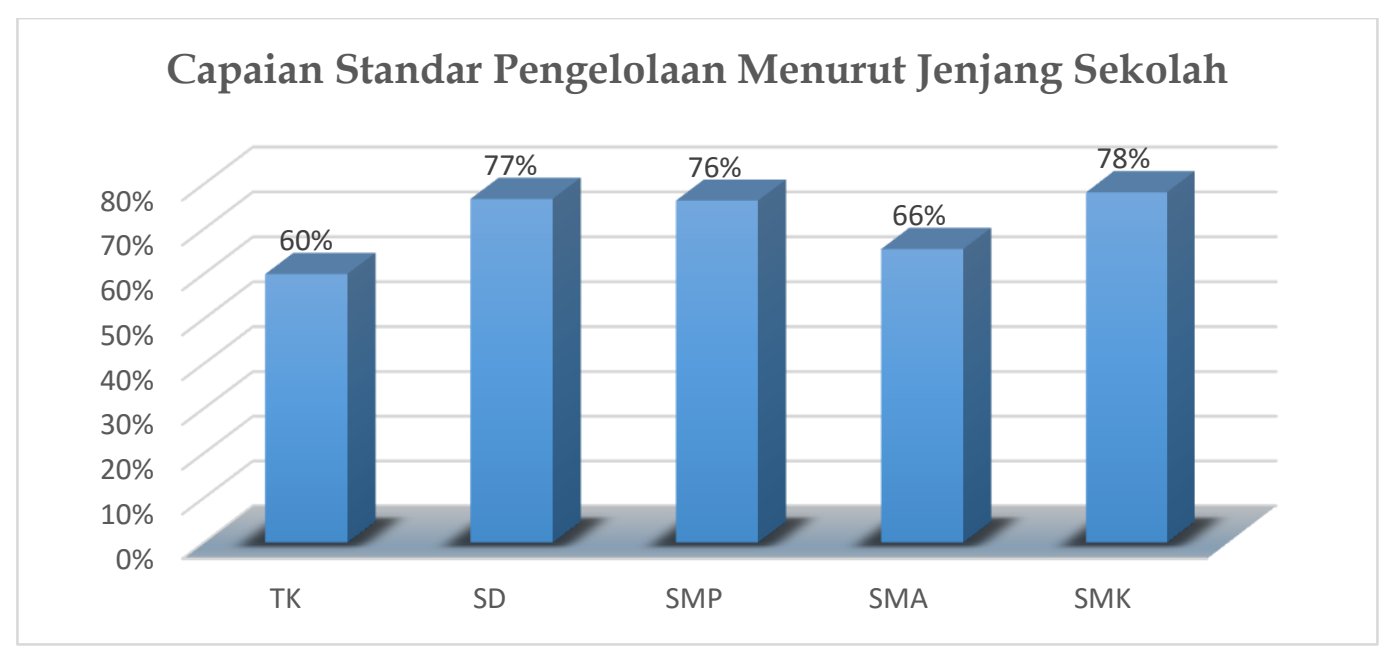

Grafik 9: Capaian Sekolah pada Srandar Pengelolaan

Pada standar pengelolaan yang ditampilkan pada grafik 9 capaian sekolah dibawah $80 \%$ dengan capaian terendah pada tingkat TK dan diikuti oleh tingkat SMA yang berada dibawah $70 \%$. Pada tingkat TK mereka secara umum belum mengintegrasikan kesetaraan gender dalam visi dan misi. Namun demikian dalam pelaksanan kegiatan akademik mereka memberikan pendidikan dan fasilitas yang sama untuk siswa laki-laki dan perempuan. Dengan pertimbangan usia peserta didik mereka belum terlalu menekankan pembedaan siswa laki-laki dan perempuan. Pada tingkat SMA sebagian sekolah bahkan sudah mencantumkan kesetaraan gender pada visi dan misi namun pelaksanaanya belum maksimal.

(7) Capaian Indikator Standar Pembiayaan. Pengaturan pembiayaan ditemukan pada standar 7.Pada standar ini dinyatakan bahwa anggaran harus menampung kegiatan dan kebutuhan siswa, tenaga pendidik dan kependidikan secara berimbang untuk laki-laki dan perempuan.Semua mereka harus dapat mengakses dan memantau anggaran sekolah serta dapat mengikuti evaluasi terhadap pembiayaan sekolah. 


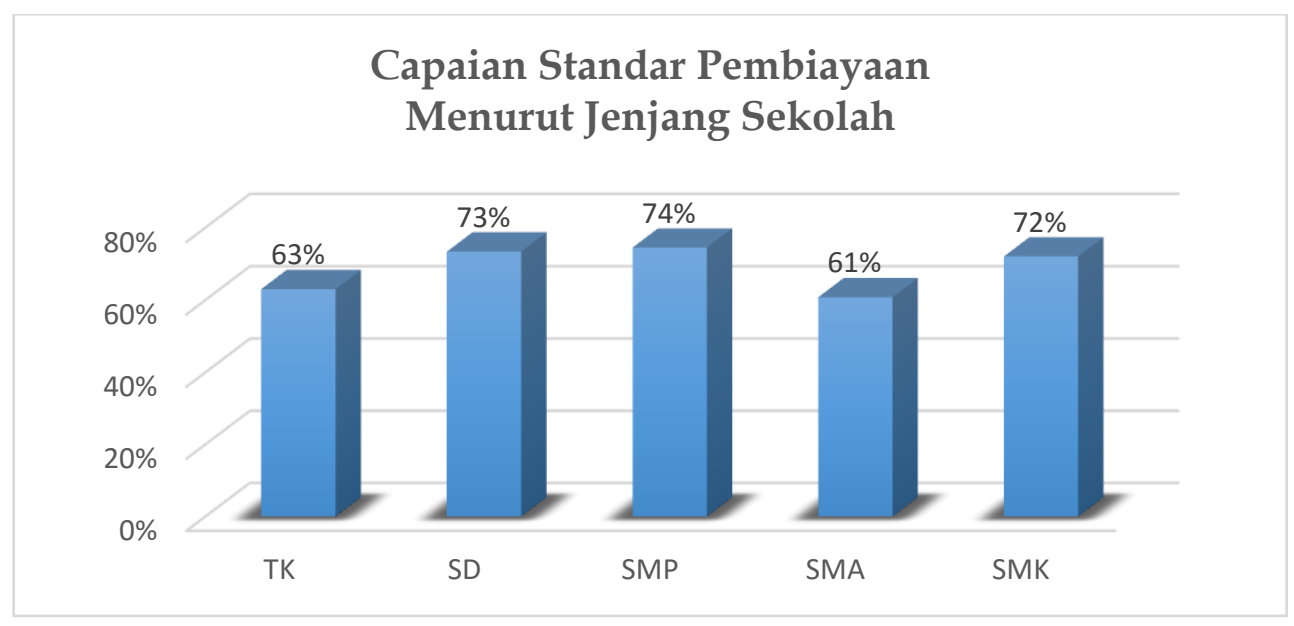

Grafik 10: Capaian Sekolah pada standar Pembiayaan

Tidak berbeda dengan standar sebelumnya, pada standar pembiayaan TK dan SMA juga mendapatkan nilai yang lebih rendah dari jenjang sekolah lainnya. Tidak ditemukan sekolah yang khusus mengangarkan kegiatan berbasis sekolah berwawasan gender pada programnya. Secara umum juga belum semua pihak punya akses dan evaluasi terhadap anggaran sekolah.

(8) Capaian Indikator Standar

Penilaian. Standar 8 merupakan standar tentang penilaian. Menurut standar ini, penilaian harus mempertimbangkan budaya, perubahan karakter serta kodrat laki-laki dan perempuan. Secara umum sekolah tidak bermasalah dengan penilaian karena selama ini mereka juga tidak membedakan siswa laki-laki dan perempuan dalam penilaian. Namun demikian sekolah tidak mendapatkan capaian yang tinggi pada standar ini karena kegiatan tidak dibuat dalam rencana tertulis.

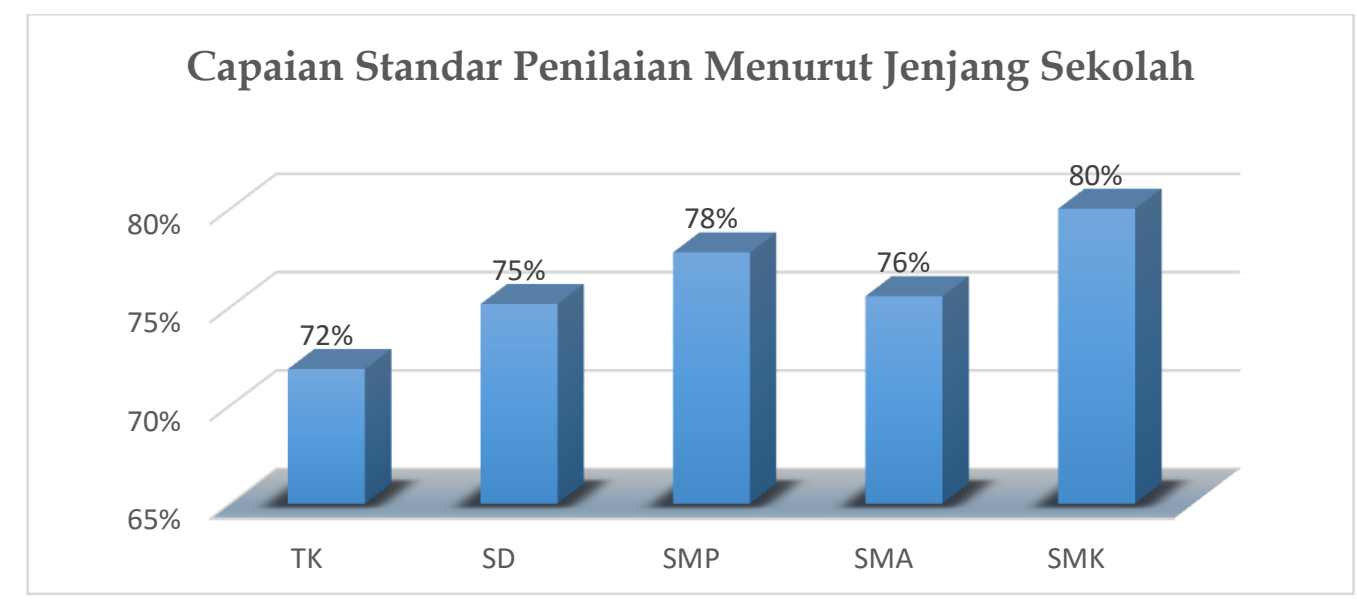

Grafik 11: Capaian Sekolah pada standar Penilaian 
(9) Capaian Indikator Standar Peserta Didik. Keberadaan peserta didik diatur pada standar nomer 9. Pada standar ini disebutkan bahwa jumlah siswa laki-laki dan perempuan harus berimbang sesuai kondisi. Semua siswa berhak mendapatkan fasilitas lingkungan yang responsif gender, tidak terjadi penyimpangan dan pelecehan berbasis gender sehingga semua siswa dapat kesempatan untuk berprestasi secara optimal.

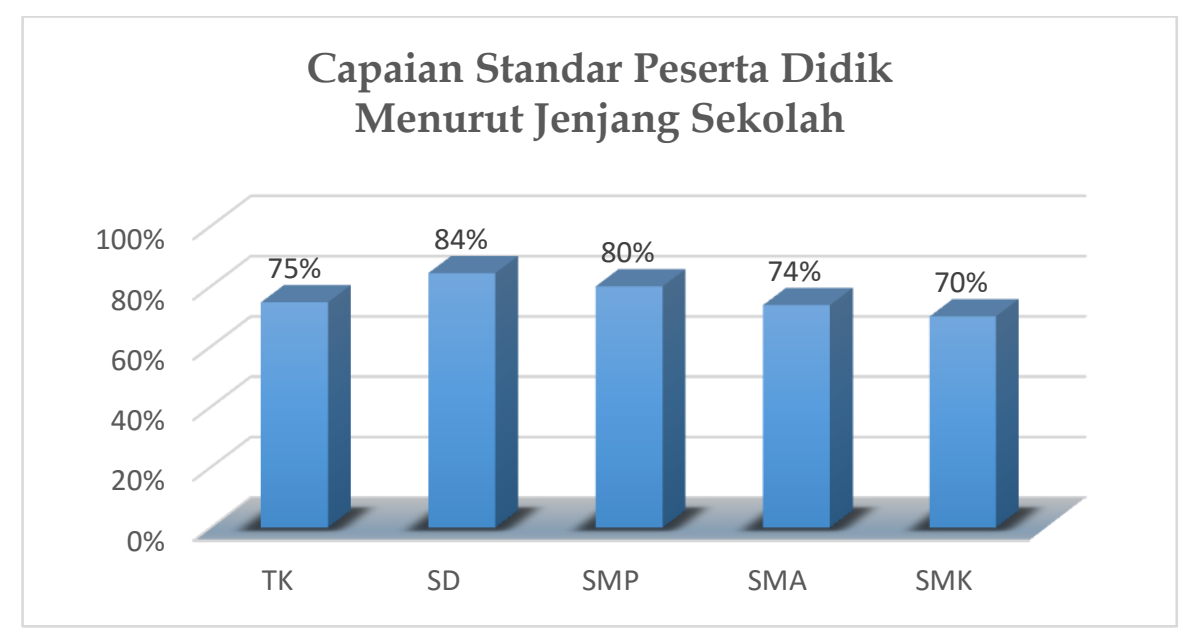

Grafik 12: Capaian Sekolah pada Standar Peserta didik

Indikator 9 mengatur tentang standar peserta didik. Pada standar ini sekolah dituntut untuk tidak membedakan penerimaan antara siswa laki-laki dan perempuan. Dilihat pada grafik diatas ternyata SMK memiliki nilai capaian terendah. Hal ini terjadi karena jumlah siswa laki-laki dan perempuan pada SMK sangat ditentukan olah jurusan yang mereka miliki. Terdapat kecendrungan lebih banyak siswa laki-laki pada jurusan tertentu seperti listrik dan otomotif. Sekolah sudah mencoba untuk mensosialisasikan jurusan tersebut kepada masyarakat namun image masyarakat tentang kekhasan jurusan laki-laki dan perempuan belum berobah.

\section{Capaian Indikator Standar}

\section{Partisipasi Masyarakat}

Pada standar 10 diatur partisipasi masyarakat yang menyangkut komite sekolah dan keanggotaannya. Anggota komite sekolah harus berimbang antara lakilaki dan perempuan pada setiap jabatan. Melalui komite sekolah ini akan terjalin komunikasi antara sekolah dan orang tua untuk meningkatkan kesadaran masyarakat akan kebutuhan responsive gender. 


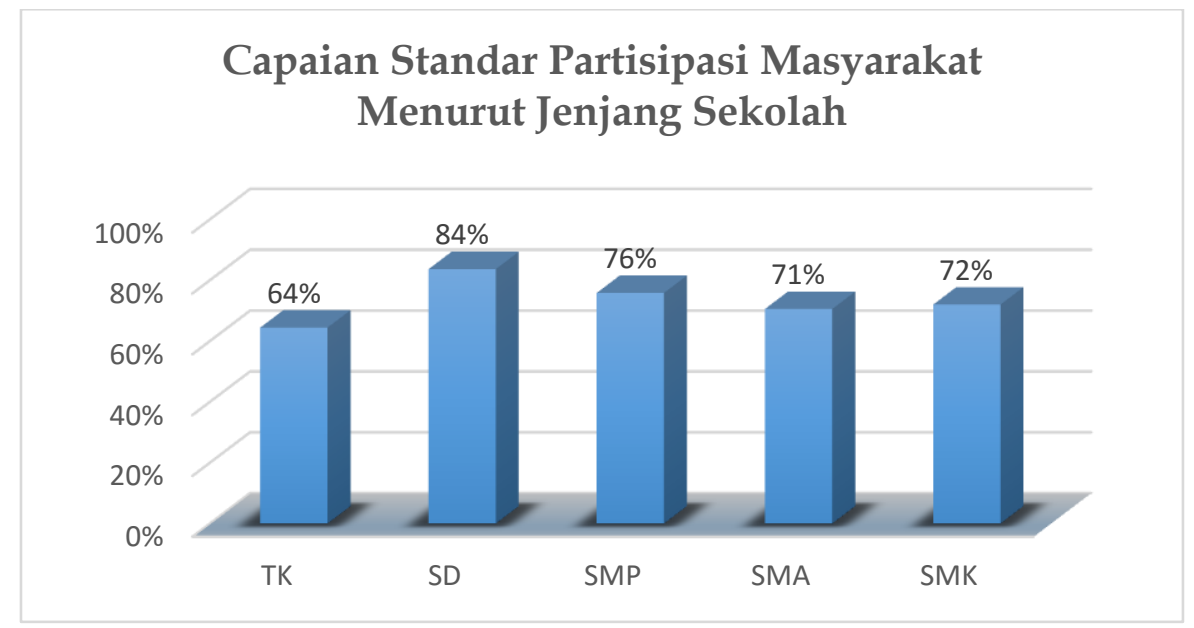

Grafik 13: Capaian Sekolah pada Standar Partisipasi Masyarakat

Pada standar partisipasi masyarakat digambarkan pada grafik 13 bahwa SD medapat capaian yang tertinggi. Hal ini terjadi karena pada tingkat sekolah dasar keterlibatan orang tua di sekolah masih tinggi. Secara umum pada komite sekolah masih dominan anggota laki-laki meskipun dalam urusan siswa disekolah lebih banyak orangtua perempuan yang berurusan.

\section{KESIMPULAN DAN SARAN}

Dari hasil pengolahan data penilaian pelaksanaan program sekolah berwawasan gender di Propinsi Riau dapat disimpulkan hal-hal berikut: (1) secara umum sekolah di Propinsi Riau sudah mulai mengenal program sekolah berwawasan gender dan sudah punya keinginan untuk menjalankannya; (2) dari temuan lapangan capaian sekolah pada indikator sekolah berwawasan gender cukup baik namun demikian hal ini belum karena sekolah sudah menjalankan program akan tetapi karena secara umum selama ini tidak ditemukan masalah yang serius tentang bias gender disekolah; (3) Secara umum SMA capaiannya lebih rendah dari jenjang sekolah lainnya.; (4) Standar Sarana dan Prasarana merupakan indikator yang paling rendah capaiannya pada semua jenjang sekolah

Dari hasil temuan diatas dapat diberikan beberapa saran yang dapat meningkatkan capaian semua standar pada indicator sekolah berwawasan gender yaitu: (1) pemerintah propinsi Riau melalui Dinas Pendidikan disarankan untuk melakukan pendampingan ke sekolah untuk perencanaan dan pelaksanaan program sekolah berwawasan gender terutama pada standar proses; (2) sekolah perlu diberikan dana untuk sarana dan prasaran untuk meningkatkan layanan kepada siswa terutama melalui sarana dan prasarana; (3) dinas Pendidikan melalui bidang terkait perlu melakukan kajian lanjutan untuk 
melihat faktor rendahnya capaian ditingkat

SMA; (4) dinas Kabupaten/kota yang memiliki capaian rendah disarankan untuk meningkatkan komunikasi dalam menjalankan program dengan Dinas Pendidikan Tingkat Propinsi,

\section{Endnotes:}

Ace Suryadi dan Ecep Idris, Kesetaraan Gender dalam Bidang Pendidikan, cet 1, Bandung Genesindo, 2004, hlm 19

2 Mansour Faqih, Gender Sebagai Alat Anilisis Sosial, edisi 4 november 1996

3 Mufidah Ch, Paradigma Gender, Malang, Bayumedia Publishing, 2003 hlm 4-6

\section{DAFTAR PUSTAKA}

Ace Suryadi dan Ecep Idris, Kesetaraan Gender dalam Bidang Pendidikan, cet 1, Bandung Genesindo, 2004

Mansour Faqih, Gender Sebagai Alat Anilisis Sosial, edisi 4 November 1996

Mufidah Ch, Paradigma Gender, Malang, Bayumedia Publishing, 2003

Philip Robinson, Sosiologi Pendidikan, Jakarta : Rajawali Press, 1981, hlm 277 